\title{
ジオメンブレンを用いた農業用水路の 漏水補修工法の性能評価
}

\author{
渡嘉敷勝 $1 \cdot$ 石神暁郎 $2 \cdot$ 高橋晃 $3 \cdot$ 森充広 $4 \cdot$ 増川晋 $5 \cdot$ 長束勇 6
}

\begin{abstract}
近年, 農業用水路では, 劣化などにより低下した機能の回復・向上を目的とした種々の補修・補強工法の開 発・適用が進められている，筆者らは，主に漏水などの対策として，遮水性能に優れるジオメンブレンを活用 した補修工法の開発を行っている. ジオメンブレンは, フィルダムや眝水池の表面遮水などに多くの実績を持 つが, 主として静水中での使用を想定している場合が多く, 農業用水路のような流水中に唒されることを想定 した性能評価については，十分になされていない，本報では，ジオメンブレンをコンクリート製農業用水路の 漏水補修に適用した工法について, 而摩耗性や水路目地への追従性など, 農業用水路の要求性能, 施工条件お よび曝露条件を想定した性能評価を実施したので，その結果を報告する.
\end{abstract}

キーワード : ジオメンブレン, 農業用水路, 漏水, 補修, 性能評価

\section{1.はじめに}

農業用水路では，コンクリート躯体自体の強度は健全 に保持されているものの, (1)通水表面において摩耗が進 行し, 局部的な侵食・穿孔に至り, 漏水を生じている事 例や，(2)コンクリートブロック積水路の継目部分から漏 水を生じている事例, あるいは, (3)目地材の劣化・脱落 により, 水路目地から漏水を生じている事例などがみら れる (図一 1参照)．こうした農業用水路における漏水 は, 水路の水利機能を著しく低下させるだけでなく, 漏 出した水が周囲の土壌や住環境に悪影響を与えるなど, 水路管理者, 周辺受益者および周辺住民にとって重要な 解決すべき課題となっている.
こうした機能低下を生じた農業用水路に対し，近年， その機能の回復・向上を目的とした種々の補修・補強工 法の開発・適用が進められている. その中で, 筆者らは, 主に漏水などの対策として, 遮水性能に優れるジオメン ブレンを活用した補修工法の開発を行っている1). ジオ メンブレンは, 遮水性や耐久性に優れる材料として多く の実績を有するものであるが，フィルダムや貯水池の表 面遮水など，主に静水中で使用することを想定している 場合が多く, 農業用水路のような流水中に唒されること を想定した性能評価については，十分になされていない， 本報では，ジオメンブレンをコンクリート製農業用水 路の漏水補修に適用した工法について, 而摩耗性, 水路 目地への追従性, 通水表面における平滑性保持性など,

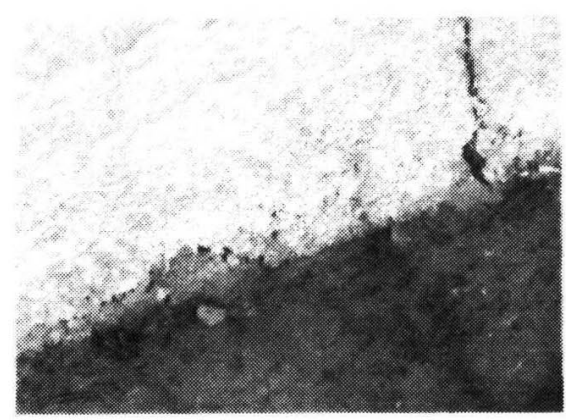

(1)侵食・穿孔による漏水

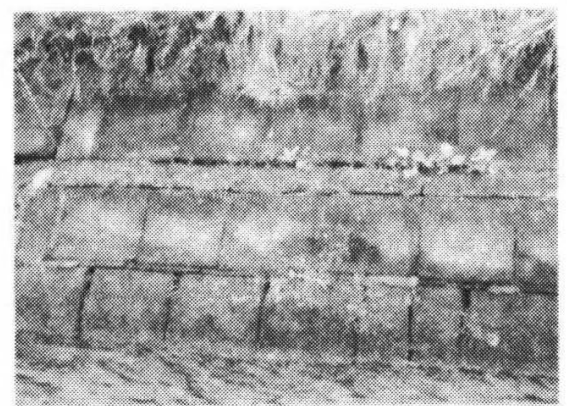

(2)プロック積水路の継目部分からの漏水

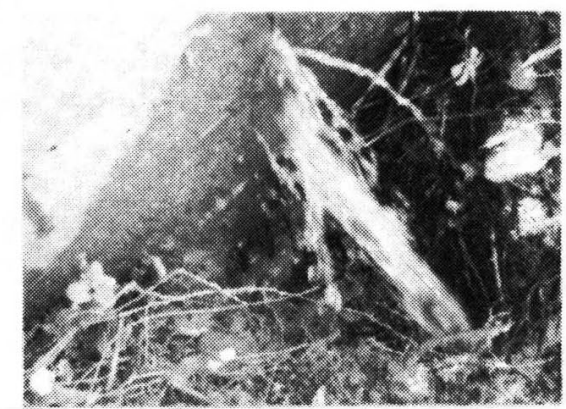

(3)水路目地からの漏水

図－1 農業用水路の漏水による水利機能の低下 
農業用水路の要求性能，施工条件およひ曝露条件を想定 した性能評価方法を検討し，これに基づく性能評価を実 施したので，その結果を報告する.

\section{2. 漏水補修工法の概要}

開発中の漏水補修工法の概要を図一 2 に示す．本補修 工法は，(1)既設水路の表面を高圧水洗浄した後，(2)特殊 アンカーボルトにて固定用治具をスポット的に設置し，

(3)ジオメンブレン（特殊ウレタンー塩化ビニル系シート 材料）を，設㯰した固定用治具に電磁溶着する．これに より，コンクリートブロック積水路のように接着型補修 工法の適用が困難な場合においても，水路の漏水防止対 策が可能となる. ジオメンブレンはポリエステル長繊維 による補強複合タイプを使用し，厚さは1.55mmである.

ジオメンブレン同士の継目部は, 加熱溶着により一 体化を図り，端部処理は，ステンレス製平鋼，ブチルゴ ム系止水板および特殊工ポキシ樹脂シール材によりシー 儿処理を行う. なお, 固定用治具設置の際は, 特殊アン カーボルトの引抜き抵抗性および而久性向上のため, ボ ルトに特殊エポキシ樹脂接着剤を塗布する. また，端部 が水路水面以深に位置する場合は，ステンレス製平鋼な どが水路内の凸部とならないよう, 溝状のはつり処理お よびポリマーセメントモルタルによる断面修復処理を行 い, 水路内表面の平滑性を確保する. さらに，既設水路 から生じる背面水を水路内に排除するため, 逆止弁を内 蔵した排水装置を設置する゙1.

本工法は，以上の材料，構造および施工方法を採用す ることにより, (1)従来の農業用水路の漏水補修工法に比 べ工期短縮が図られる，(2)品質の安定した均一な施工が 可能となる, (3)ジオメンブレンは電磁溶着により固定さ れるためアンカーボルトなどが露出せず，端部処理も含 め, 水路内表面の平滑性が確保される, (4)可塑剤を含ま ないジオメンブレンの使用により，水路内の水質に悪影 響を及ぼさず，また，材料の高耐久性化が図られる，(5) 施工後の部分補修の際も, 専用機械や特殊技能を要さず,

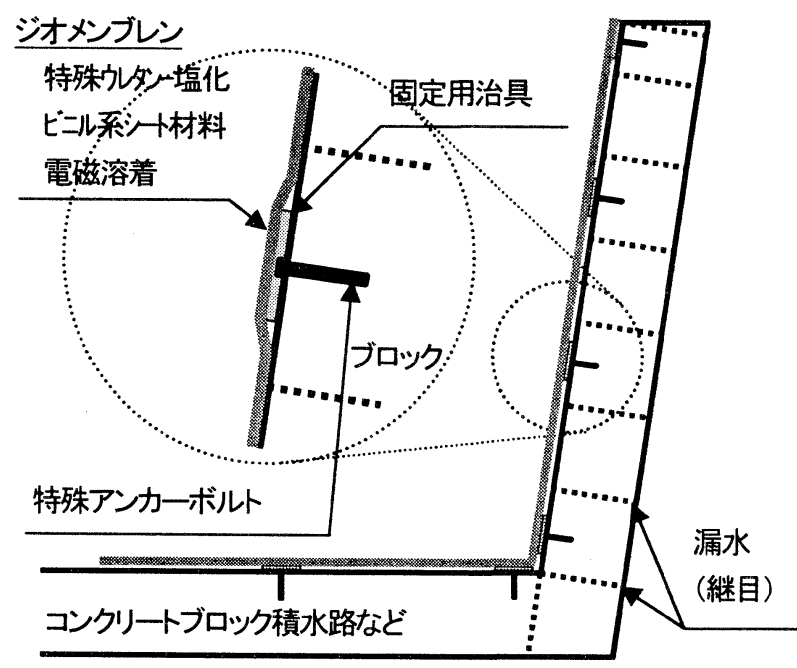

図一－＼cjkstart漏水補修工法の概要
維持管理性に優れる，などの特長を有する1).

\section{3. 農業用水路の補修工法に要求する性能と評価 方法の検討}

農業用水路における漏水発生の原因には, 前述のよう に, 摩耗, 継目, 目地などが挙げられる. 一方, 農業用 水路の要求性能としては, 水利機能, 水理機能, 構造機 能といった機能性に関する使用性能が重要となる．また， 農業用水路の補修を行う際の施工条件からは，施設供用 下, 非潅溉期 (冬期) の低温下および湿潤環境下の各条 件下での施工に対応することが求められ，曝露条件とし ては, 漏水発生の一因となる摩耗作用のほか, 流水に唒 されることによる化学的変質, 紫外線劣化などが挙げら れるか。

以上の漏水発生原因, 農業用水路の要求性能, 農業用 水路における施工条件およひ曝露条件を考慮し, 本性能 評価では, 農業用水路の補修工法に要求する性能の中で, ジオメンブレンの耐摩耗性, 水路目地への追従性, 通水 表面における平滑性保持性, 化学的変質に対する抵抗性 および而候性について確認することとした。

以下に，各性能評価方法を示す。

\section{（1）耐摩耗性}

農業用水路の摩耗した通水表面の分析結果では, 摩耗 の発生原因は, 物理的な砂磷のすり減り作用によるもの だけではなく, 水路内の流水に晒されることによるコン クリートの化学的な変質が, その要因の一つとなり得る ことが報告されている゙. 一方, 砂碟のすり減り作用に は，砂分によるすり磨き作用のほか，礫分による衝撃的 摩耗作用が含まれると考えられる. そこで, 耐摩耗性の 評価では，流水による摩耗を想定した試験（以下，水流 摩耗試験と呼ぶ），すり磨き作用を想定した試験（以下， すり磨き摩耗試験と呼ぶ），衝撃的摩耗作用を想定した 試験（以下，衝撃摩耗試験と呼ぶ），の3試験方法を選

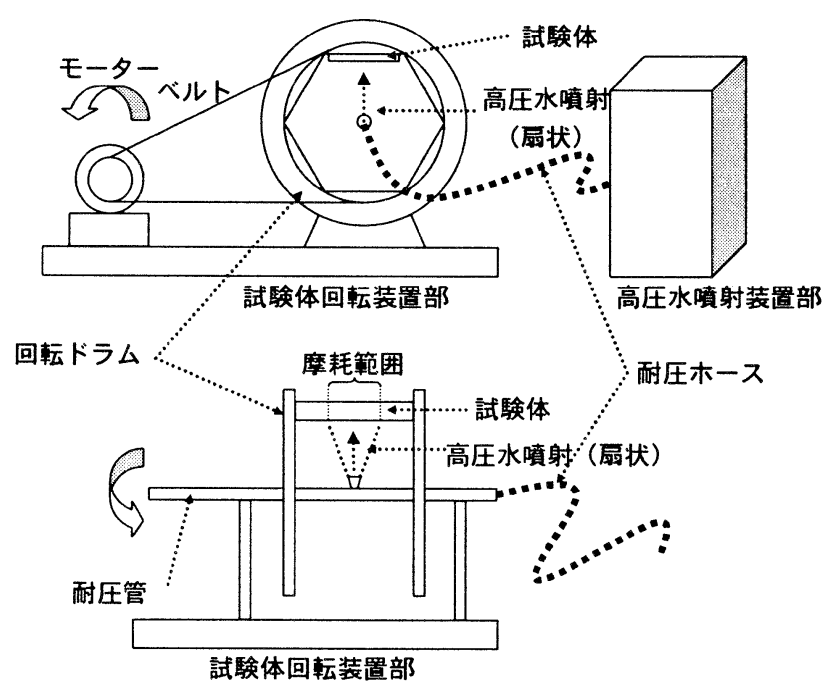

図一 3 水流摩耗試験の概要 

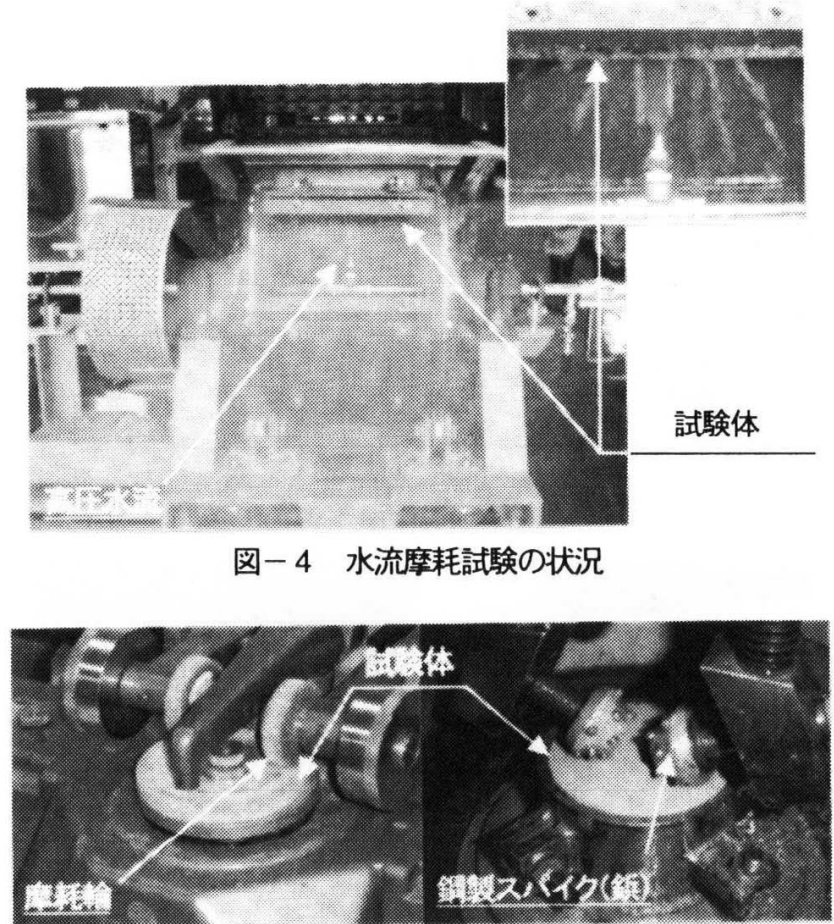

図一 5 すり磨き摩耗試験 の状況

図一 6 衝撃摩耗試験 の状況

定し実施した. 水流摩耗試験の概要を図一 3 に, 各試験 の状況を図ー4〜6に示す.

水流摩耗試験は, 高厈水流を用いることで, 農業用水 路にみられる, 表面のモルタルが選択的に流出し, 粗骨 材のみが露出する摩耗現象（図一7参照）を再現できる 試験方法である.6体の試験体を正六角形状に，回転ド ラム内部に試験表面を内側に向けて設置し, ドラム中心 部分より噴射される高圧水を，6体の試験体が均等に受 けることができるよう一定の速度で回転する「試験体回 転装置部」と, 高圧ポンプを利用し, 一定の条件（最大 噴射圧力4.9MPa，最大噴射水量24.11/min）で高圧水を扇 状に噴射し，噴射を受けた試験体表面を摩耗させる「高 圧水噴射装置部」の，2装置部より構成される2。.

すり磨き摩耗試験は, 摩耗輪を用い, 硬質な材料を摩 擦㫮動させることで, すり磨き作用による摩耗現象を再 現する試験方法である. 本試験は, IIS K 7204「プラス チックー摩耗輪による摩耗試験方法」に準拠し実施した。

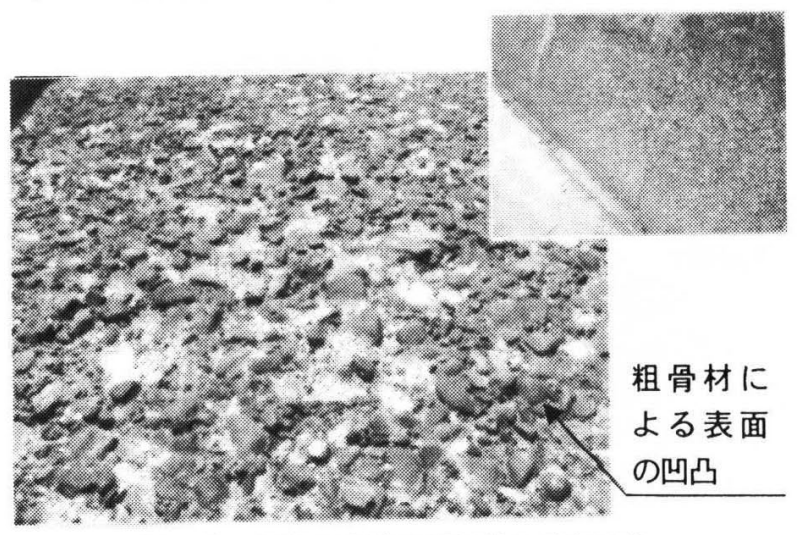

図-7 農業用水路の選択的な摩耗現象
摩耗輪の荷重は10Nとし, 摩耗輪タイプはH22を使用し た.

衝撃摩耗試験では，鋼製スパイク（鋲）を用い， $300 \mathrm{~N}$ という比較的大きな荷重を連続的に回転させなが ら加えることで, 衝撃的摩耗作用による摩耗垷象を再現 することを目的としている. 本試験方法は，一般にスパ イクラベリング試験と呼ばれ, 道路舗装材料のスパイク タイヤによる摩耗に対する抵抗性を, 試験・評価する試 験方法として採用されている.

\section{（2）水路目地への追従性}

コンクリート製農業用水路は, 外気温の変化により伸 張または収縮を繰り返し，その伸縮量はコンクリートの 熱膨張係数 $\left(10 \times 10^{-6} \rho \mathrm{C}\right)$ に依存する. コンクリート製 農業用水路では，一定の間隔で目地部を設け，この伸縮 を目地部で吸収している. 年間の外気温変化を $50^{\circ} \mathrm{C}$ ($10 \sim 40^{\circ} \mathrm{C}$ ) と仮定した場合, $500 \times 10^{6}$ の伸縮が発生する。 したがって, 水路10mあたりの伸縮量は5mmとなる.

水路目地からの漏水を防止するため, 目地部は水路内 に設置されたジオメンブレンにより被覆される. したが って, ジオメンブレンには水路目地への追従性が要求さ れる. 目地部の概要を図一 8 に示す.

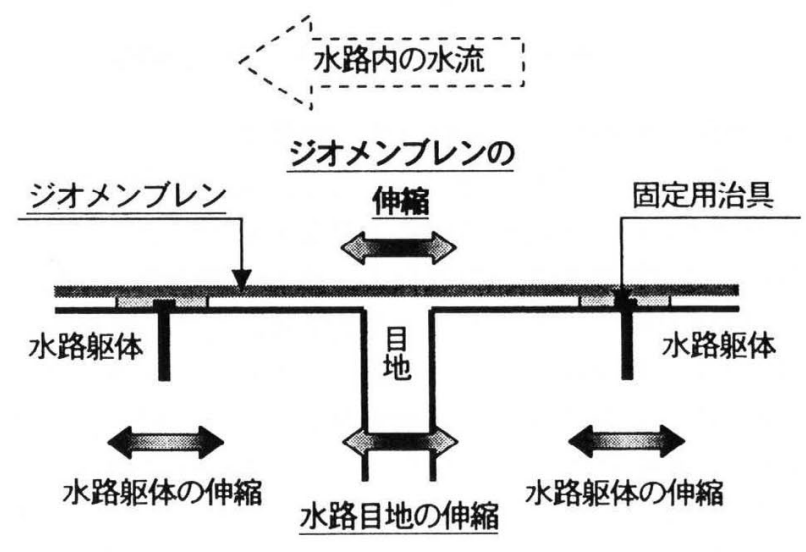

図一8 目地部の概要

ジオメンブレンは固定用治具に一定の間隔で溶着され るため, 水路目地の伸縮の発生と同時に, ジオメンブレ ンにも伸縮が発生する. そこで, 水路目地への追従性の 評価では, 引張試験および引張試験方法による伸縮繰り 返し試験を実施した. 引張試験方法は, JIS L 1096「一般 織物試験方法」に準拠し，つかみ間距離は200 $\mathrm{mm}$ とした. また, 伸縮繰り返し試験の伸縮量は, 水路10mあたりの 伸縮量 $5 \mathrm{~mm}$ (つかみ間距離に対して25\%），および $15 \mathrm{~mm}$ (同75\%) とし, 繰り返し回数は50回とした.

\section{（3）通水表面における平滑性保持性}

農業用水路では, その水理機能の確保のため, 通水表 面に損ける平滑性が要求される. 農業用水路の補修では, 摩耗により生じた凹凸面の影響による平滑性の低下を, 回復・向上させることが求められる. 補修後の水路の平 
滑性を低下させる要因としては, 摩耗による凹凸の再発 生が考えられる.しかし，ジオメンブレンを用いた本補 修工法においては，ジオメンブレン自体の摩耗による平 滑性の低下はほとんどない。一方, 本工法では, ジオメ ンブレンを設置する際，摩耗した水路の凹凸面に直接敷 設する施工方法を採用することから，水路内の水圧によ りジオメンブレンがロ凸面に押し付けられ，平滑性を維 持できない可能性がある. そこで, 通水表面における平 滑性保持性の評価では, 而水圧性試験》を行い, 試験前 後の平滑性を比較した. 而水圧性試験では, 水路の凹凸 面を再現するため, 基盤材料には $20 \mathrm{~mm}$ 単粒度砕石（S20）を用いた。なお，加圧条件は03MPa・672h（28日 間）とした。而水圧性試験の概要を図一 9 に示す.

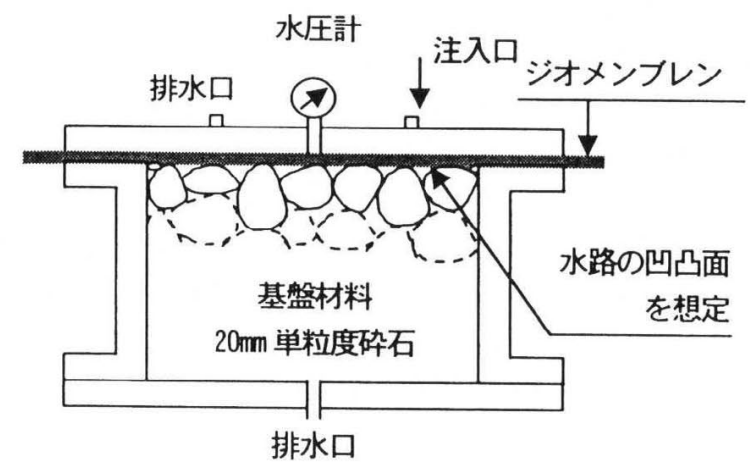

図-9 耐水圧性試験（平滑性保持性）の概要

（4）化学的変質に対する抵抗性・耐候性

農業用水路の流水に晒されることによる化学的変質や， 紫外線劣化は，局部的な侵食・穿孔の原因になるの之同 時に, 強度特性や水理特性など, 他の性能の低下を助長 させる要因にもなり得る. 化学的変質に対する抵抗性の 評価では, 而薬品性試験を実施し, 而候性の評価では, 促進而候性試験および屋外曝露を実施した。而菜品性試 験は, JIS K 7114「プラスチックの耐薬品性試験方法」 に準拠した。 また，促進而候性試験はキセノンランプ法 およびメタルハライドランプ法に準拠し，屋外曝露は試 験施工箅所（近畿地方, 四国地方）および茨城県つくば 市内で䒠施中である.

\section{4. 性能評価結果および考察}

\section{（1）耐摩耗性}

水流摩耗試験の結果（摩耗深さ变化）を図一10に，す り磨き摩耗試験の結果（摩耗減量変化）を図一11に, 衝 撃摩耗試験の結果（摩耗減量変化）を図一12に示す。な お, 各試験では, 比較のため, コンクリート試験体

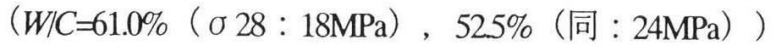
による試験を併せて行った。

水流摩耗試験では, ジオメンブレンの摩耗はみられな かった. 一方, すり磨き摩耗試験, 衝撃摩耗試験では, ジオメンブレンの摩耗が確認された. すり磨き摩耗試験 では, 1,000回転で約0.23g摩耗し、コンクリートの摩耗
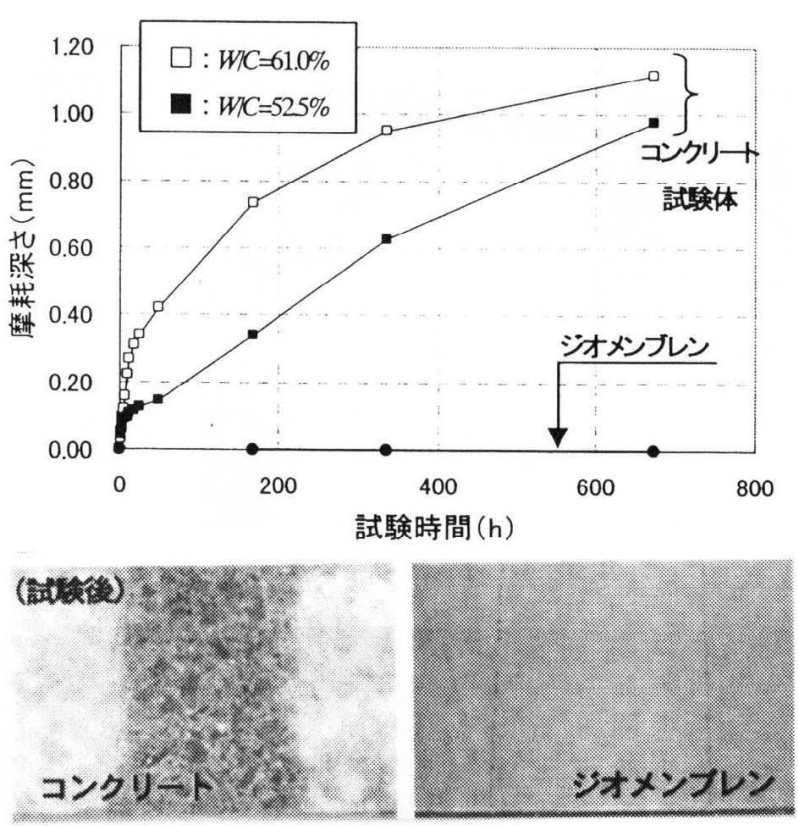

図－10 水流摩耗試験結果

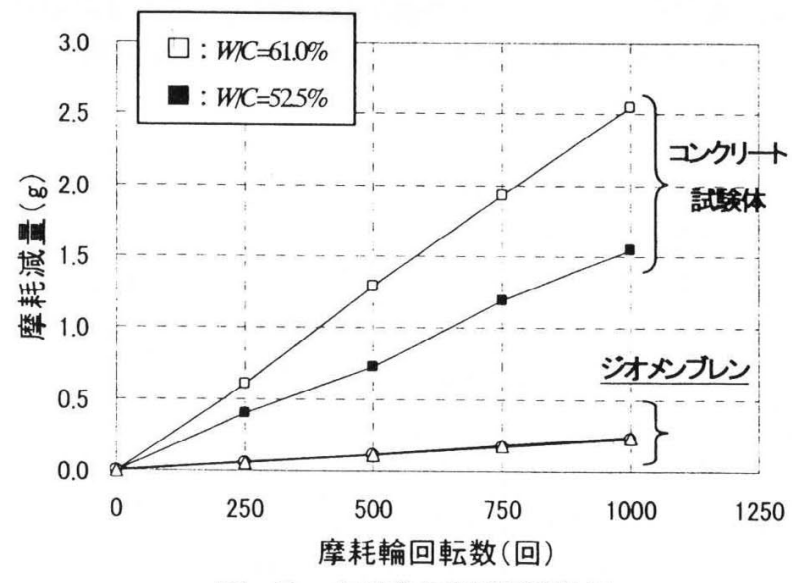

図-11 すり磨き摩耗試験結果

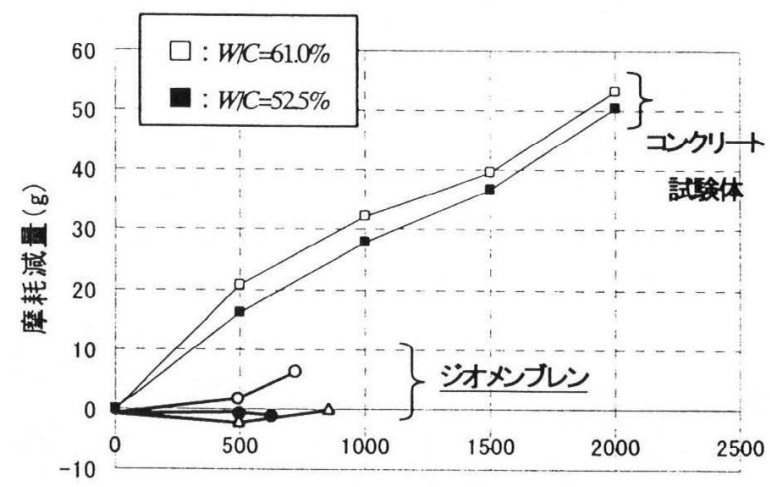

鋼製スパイク回転数(回)

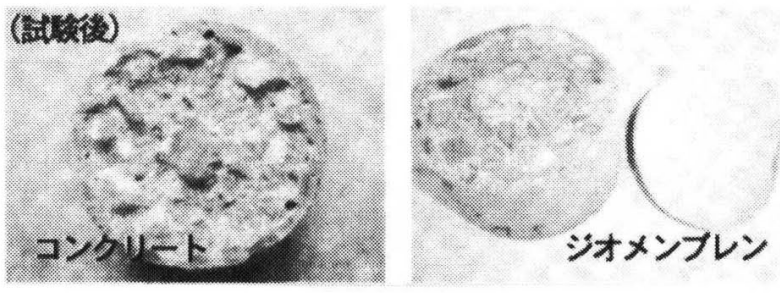

図-12 衝撃摩耗試験結果 
減量の9〜15\%程度であった. また, 衝撃摩耗試験では, その衝撃力により試験中にジオメンブレンが著しく変形 し，500 1,000回転で, 基盤材料からの剥離に至った.

以上の結果より, ジオメンブレンを用いた本工法では, 衝撃的に作用する摩耗に対しては変状を生じる可能性が あるものの，いずれの試験においてもコンクリートに比 べ而摩耗性に優れることから, 農業用水路への適用につ いては問題ないものと考えられる. 評価方法としては, 施工現場での耐久性調査などから, 試験時間・回転数と 供用年数との関係を確認し, 劣化予測や耐用年数などの 定量的性能評価を行うことが重要であると考えられる。

\section{（2）水路目地への追従性}

ジオメンブレンの引張試験では, 試験体数は10体とし た. 引張強度は $1834 \sim 1904 \mathrm{~N} / 3 \mathrm{~cm}$ (平均值： 1868.4 $\mathrm{N} / 3 \mathrm{~cm}$ ），破断時の伸び率は $18.0 \sim 21.0 \%$ （平均值： 195\%）であった. 固定用治具溶着部間の最小距離を $200 \mathrm{~mm}$ と仮定すると, 最大約 $40 \mathrm{~mm}$ の伸縮量を吸収でき ることが分かった.

伸縮繰り返し試験の結果を図ー13（伸縮量 $5 \mathrm{~mm}$ ) およ び図ー14（伸縮量 $15 \mathrm{~mm}$ ）に示す。伸縮量 $5 \mathrm{~mm}$ の場合, 1 回目の載荷では約260Nの荷重を示すのに対し，50回目の

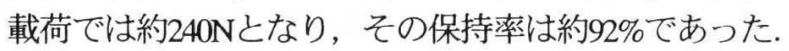
一方, 伸縮量 $15 \mathrm{~mm}$ の場合は, 1 回目の載荷では荷重は約 540Nを示すのに対し，50回目の載荷では約470Nとなり， その保持率は約 $88 \%$ であった. 現場での固定用治具溶着

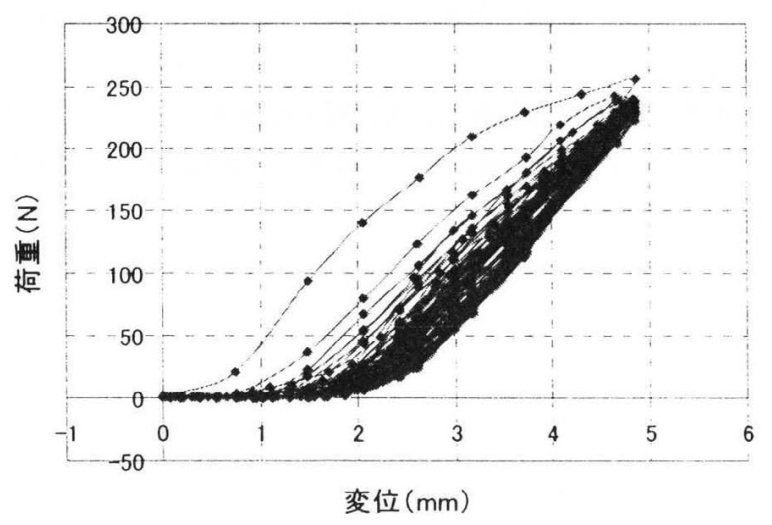

図-13 伸縮繰り返し試験結果（5mm（2.5\%））

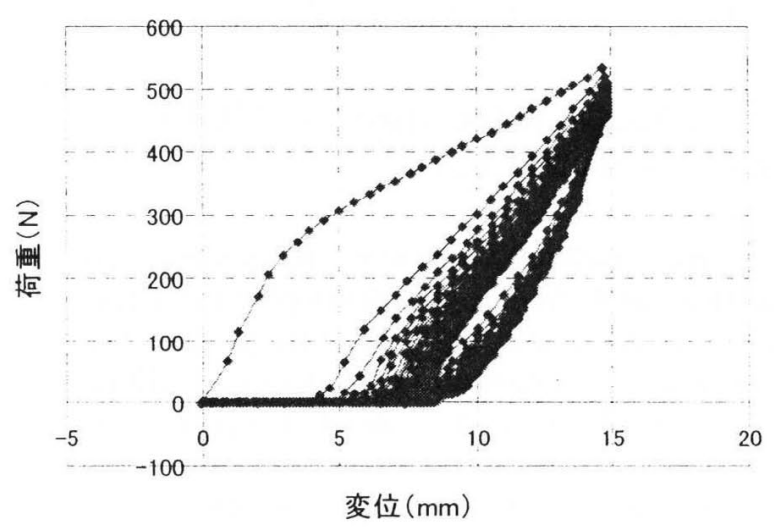

図-14 伸縮繰り返し試験結果（15mm（7.5\%）
部間の距離を $200 \mathrm{~mm}$ とした場合, $50^{\circ} \mathrm{C}$ の外気温変化を 50 回繰り返しても約 $90 \% の$ 保持率を示し，その3倍量の伸 縮に対してもほぼ同等の保持率を示すことが分かった.

評価方法としては, 引張応力や伸縮繰り返しを受け た際の耐水圧性や而喉性など，実供用下に則した評価方 法へ発展させていくことが重要であると考えられる.

\section{（3）通水表面における平滑性保持性}

而水圧性試験における基盤材料の表面からの深さの分 布およびジオメンブレンの耐水圧性試験後の表面からの 深さの分布を図一15に示す.

基盤材料では, 平均深さ $4.3 \mathrm{~mm}$, 最大深さ $24.5 \mathrm{~mm}$, 最 大高低差273mmであった. これに対し、ジオメンブレ ンを敷設したものは, 平均深さ $0.2 \mathrm{~mm}$, 最大深さ $25 \mathrm{~mm}$, 最大高低差 $5.4 \mathrm{~mm}$ であった. 試験後の外観観察からは凹 凸の発生がみられたが, 平均深さにして1/20程度であり, 平滑性を失うまでの状態には至らないことが分かった. この要因としては, 本工法のジオメンブレンには臓維を 含有する補強複合夕イプを採用しているため, 高水圧下 においても剛性が発揮されたことなどが考えられる.

評価方法としては, 農業用水路では通水量が季節に より著しく変化することが予想されるため, 加圧一除圧 の繰り返しによる応力状態の変化, それに伴う平滑性保 持性を検証することが重要であると考えられる.

なお, 試験中の水压低下などはなく, 試験後の試験 体に損傷などはみられなかった.
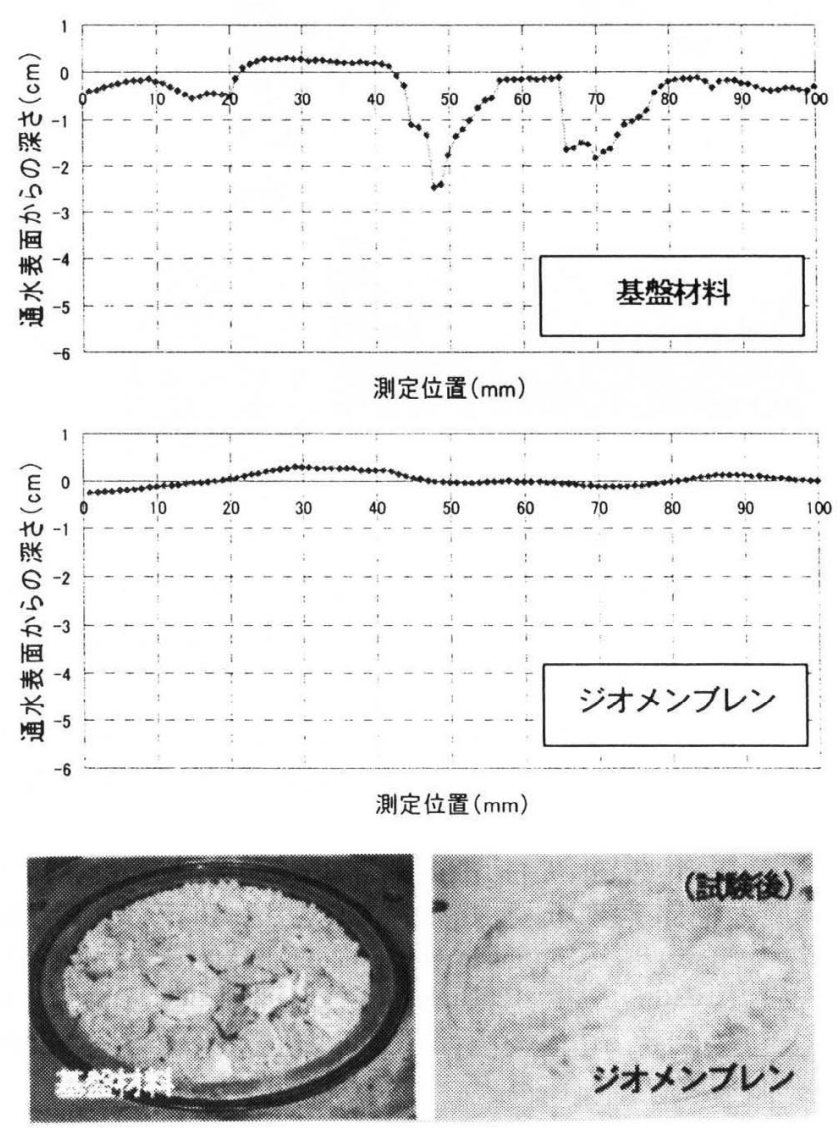

図一15 平滑性保持性（耐水圧性）試験結果 
（4）化学的変質に対する抵抗性・耐候性

而搝品性試験では, $10 \mathrm{~cm} \times 10 \mathrm{~cm}$ の試験体を各試験液 $\left(\mathrm{H}_{2} \mathrm{SO}_{4} 10 \%\right.$ aq, $\mathrm{HCl} 10 \%$ aq, $\mathrm{HNO}_{3} 10 \% \mathrm{aq}, \mathrm{NaOH} 10 \%$ aq, $\mathrm{Ca}(\mathrm{OH})_{2} 10 \%$ aq, $\left.\mathrm{NH}_{3} 10 \% \mathrm{aq}\right)$ に10日間浸漬し, 浸漬後の 外観を観察した。ひひ割れ・亀裂・膨潤・溶解などの異 常はみられず，化学的変質に対する抵抗性を有すること が分かった.

促進耐候性試験では，各試験法ともに，3,000時間終 了時点で変状はみられなかった，屋外曝露について，試 験施工箇所の事例を図一16および図ー17に示す．施工後 約1年3ヶ月および3ヶ月が経過しているが，特に変状は みられない，今後も追跡調査を行い，本工法の耐久性に ついて確認を行うとともに, 前述の性能評価方法につい て，検証を加える予定である.

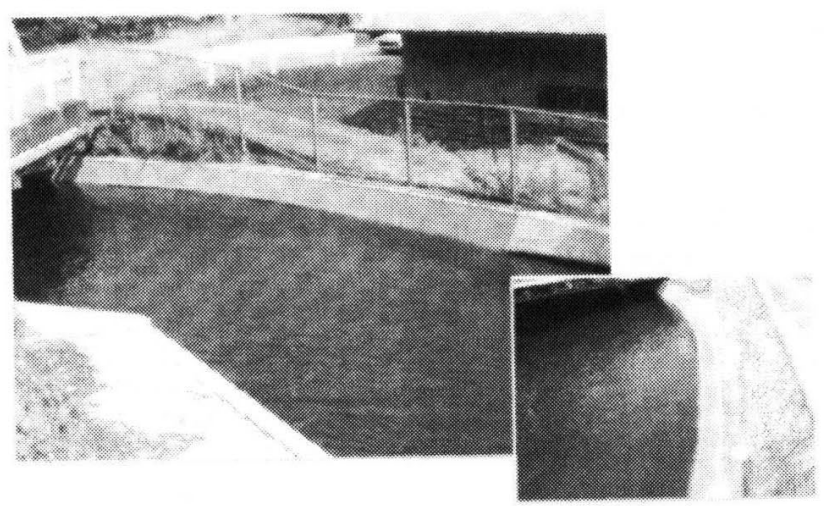

図一 16 施工後 1 年 3 ヶ月の状況（近载地方）

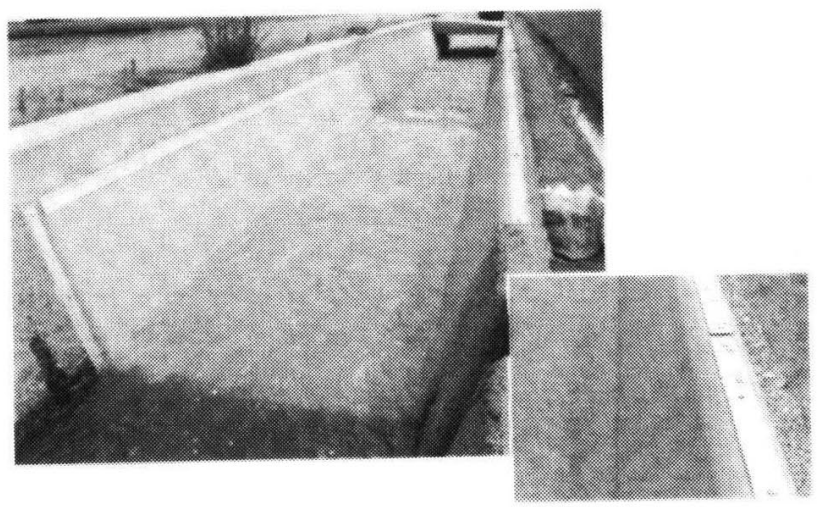

図-17 施工後3ヶ月の状况（四国地方）

\section{5. おわりに}

本報では, 現在実施している遮水性能に優れるジオメ ンブレンを活用した補修工法の開発内容と，これまであ まり検証されていなかった農業用水路の要求性能などを 想定した性能評価方法について述べるとともに，本工法 の性能評価結果を報告した. 今後は, 性能評価方法につ いて耐久性調査などから更なる検討を加えるとともに, その性能評価結果に基づき, 本補修工法の完成度を高め ていく予定である.

謝辞 : 本工法の開発および性能評価にあたり, 材料の提 供など多大な御協力を頂きました平岡織染（株）に，こ こに記して感謝の意を表します。

\section{参考文献}

1) 小俣富士夫, 竹村浩志, 山本晴彦, 梅沢俊雄, 高橋松善, 森充広, 長束勇 : ジオメンブレンを活用した農業用水路の 漏水補修, ジオシンセティックス論文集, 第19巻, pp.77-80, 2004

2) 石神暁郎, 森充広, 渡嘉敷勝, 増川晋 : 農業用水路コンク リートに生じる摩耗現象と促進試験方法に関する検討, コ ンクリート工学年次論文集, Vol.27, No.1, pp.805-810,2005

3）長束勇, 石神暁郎, 石村英明, 渡嘉敷勝, 森充広 : コンク リート構造物の補修技術の現状と農業水利分野に適用する 際の留意点, 農業工学研究所技報, 第2 202号, pp.183-196, 2004

4）長束勇 : 貯水池表面遮水工法に関する研究一主としてジオ メンブレンの利用に関して一, 農業工学研究所報告, 第38号, pp.1-131, 1999

\section{PERFORMANCE EVALUATION OF WATER LEAK REPAIR METHOD USING GEOMEMBRANE FOR IRRIGATION CANAL}

\section{Masaru TOKASHIKI, Akio ISHIGAMI, Akira TAKAHASHI, Mitsuhiro MORI, Susumu MASUKAWA and Isamu NATSUKA}

Recently, the development and application of various repair methods to recover the function that decreases due to deterioration are advanced on the irrigation canal. Authors are developing the repair method using geomembrane as measures of the water leak etc. In this report, it reports on the performance evaluation that assumes the demand performance, the construction condition, and the exposure condition of the irrigation canal about the method that applies the geomembrane to the water leak repair of the irrigation canal.

Keywords : Geomembrane, Irrigation Canal, Water Leak, Repair, Performance Evaluation 